\title{
R229Q Polymorphism of NPHS2 Gene in Group of Iraqi Children with Steroid-Resistant Nephrotic Syndrome
}

\author{
Shatha Hussain Ali, ${ }^{1}$ Rasha Kasim Mohammed, ${ }^{2}$ \\ Hussein Ali Saheb, ${ }^{3}$ and Ban A. Abdulmajeed ${ }^{1}$ \\ ${ }^{1}$ College of Medicine, Al-Nahrain University, Baghdad, Iraq \\ ${ }^{2}$ Al-Imamein Al-Kadhimein Medical City, Baghdad, Iraq \\ ${ }^{3}$ College of Pharmacy, University of Al Qadisiyah, Diwaniyah, Iraq \\ Correspondence should be addressed to Shatha Hussain Ali; shatha6ali@yahoo.com
}

Received 8 January 2017; Revised 24 March 2017; Accepted 10 April 2017; Published 26 April 2017

Academic Editor: Alessandro Amore

Copyright (C) 2017 Shatha Hussain Ali et al. This is an open access article distributed under the Creative Commons Attribution License, which permits unrestricted use, distribution, and reproduction in any medium, provided the original work is properly cited.

Background. The polymorphism R229Q is one of the most commonly reported podocin sequence variations among steroid-resistant nephrotic syndromes (SRNS). Aim of the Study. We investigated the frequency and risk of this polymorphism among a group of Iraqi children with SRNS and steroid-sensitive nephrotic syndrome (SSNS). Patients and Methods. A prospective case control study which was conducted in Al-Imamein Al-Kadhimein Medical City, spanning the period from the 1st of April 2015 to 30th of November 2015. Study sample consisted of 54 children having NS, divided into 2 groups: patients group consisted of 27 children with SRNS, and control group involved 27 children with SSNS. Both were screened by real time polymerase chain reaction for R229Q in exon 5 of NPHS2 gene. Results. Molecular study showed R229Q polymorphism in 96.3\% of SRNS and 100\% of SSNS. There were no phenotypic or histologic characteristics of patients bearing homozygous R229Q polymorphism and the patients with heterozygous R229Q polymorphism. Conclusion. Polymorphism R229Q of NPHS2 gene is prevalent in Iraqi children with SRNS and SSNS. Further study needs to be done, for other exons and polymorphism of NPHS2 gene in those patients.

\section{Introduction}

Positional cloning identified NPHS2, encoding podocin, as a causative gene in autosomal recessive SRNS, including focal segmental glomerulosclerosis (FSGS) $[1,2]$. NPHS2 is the predominant mutation found in children over the age of 1 year $[3,4]$. NPHS2 expression is restricted to the podocyte as shown by in situ hybridization studies. About 50 NPHS2 gene mutations and variants and/or nonsilent polymorphisms have been reported and recognized as potentially being involved in proteinuria. The polymorphism R229Q is one of the most commonly reported podocin sequence variations [5-7]. A functional polymorphism of NPHS2 gene, R229Q, was associated with a late-onset nephrotic syndrome and also with an increased risk of microalbuminuria in the general population [8, 9]. FSGS associated with NPHS2 mutation is uniformly steroid resistant and generally shows poor response to cyclosporine as well [10].

\section{Aim of the Study}

The aim of this study is to determine the frequency of R229Q polymorphic site of the NPHS2 gene in children with SRNS in comparison with SSNS, to study the relation of this polymorphic site to important demographics and clinical characteristics, and to determine the risk of having SRNS in relation to R229Q polymorphism.

\section{Patients and Methods}

This was a prospective case control study which was conducted in Al-Imamein Al-Kadhimein Medical City, spanning 
TABLE 1: Distribution of the study group according to demographic data.

\begin{tabular}{|c|c|c|c|c|c|}
\hline \multirow{2}{*}{ Data } & \multicolumn{2}{|c|}{ SRNS } & \multicolumn{2}{|c|}{ SSNS } & \multirow{2}{*}{$P$ value } \\
\hline & Number & $\%$ & Number & $\%$ & \\
\hline \multicolumn{6}{|l|}{ Sex } \\
\hline Male & 20 & $74.1 \%$ & 17 & $63.0 \%$ & 0.379 \\
\hline Female & 7 & $25.9 \%$ & 10 & $37.0 \%$ & 0.379 \\
\hline \multicolumn{6}{|l|}{ Age } \\
\hline 1-6 years & 7 & $25.9 \%$ & 10 & $37.0 \%$ & 0.379 \\
\hline $6-12$ years & 13 & $48.1 \%$ & 17 & $63.0 \%$ & 0.273 \\
\hline $12-18$ years & 7 & $25.9 \%$ & 0 & $0.0 \%$ & 0.005 \\
\hline \multicolumn{6}{|c|}{ Age at diagnosis } \\
\hline $1-6$ years & 17 & $63.0 \%$ & 18 & $66.7 \%$ & 0.776 \\
\hline $6-12$ years & 6 & $22.2 \%$ & 9 & $33.3 \%$ & 0.362 \\
\hline $12-18$ years & 4 & $14.8 \%$ & 0 & $0.0 \%$ & 0.038 \\
\hline \multicolumn{6}{|l|}{ Family history } \\
\hline Positive & 4 & $14.8 \%$ & 4 & $14.8 \%$ & 0.444 \\
\hline \multicolumn{6}{|l|}{ Consanguinity } \\
\hline Positive & 23 & $85.2 \%$ & 16 & $59.3 \%$ & 0.033 \\
\hline
\end{tabular}

the period from the 1st of April 2015 to 30th of November 2015. Study sample consisted of 54 children having NS. Study sample was categorized into 2 groups: patients group consisted of 27 children with SRNS. Control group involved 27 children with SSNS.

Steroid responsive NS was regarded as complete remission achieved with steroid therapy. Steroid-resistant NS was regarded as failure to achieve remission following 4-week prednisone $60 \mathrm{mg} / \mathrm{m}^{2}$ followed by three methylprednisolone pulses $[1,2]$.

3.1. Data Collected. The data collected were gender, age, age of onset of NS, steroid responsiveness, family history of NS, consanguinity, and renal biopsy if done and its report. The following laboratory investigations were performed for all children: urinalysis, plasma albumin, blood urea, and serum creatinine.

Normal values of blood urea were as follows: $1-2 \mathrm{y}=$ $1.8-5.4 \mathrm{mmol} / \mathrm{l} ;>2 \mathrm{y}=2.9-7.1 \mathrm{mmol} / \mathrm{l}$. Normal values of serum creatinine were as follows: child $=27-62 \mathrm{mmol} / \mathrm{l}$; adolescent $=44-88 \mathrm{mmol} / \mathrm{l}[4]$.

Renal insufficiency was explained by 5 stages of chronic kidney disease by estimated GFR based on serum creatinine using Schwartz formula [5].

The data about hypertension and renal insufficiency are at the last follow-up time.

Each child donated $3 \mathrm{ml}$ of venous blood, collected in an EDTA-containing blood collection tube. Samples were transferred to the molecular Pathology Laboratory, Department of Pathology, College of Medicine, Al-Nahrain University.

Genetic methods included DNA extraction and TaqMan real time PCR genotyping.

3.2. Statistical Analysis. The SPSS version 21 was employed in this research. Chi-square test was used for comparison of frequencies and $t$ tests were used for comparing means. Odd ratio was used to discriminate between alleles in patients and control.

\section{Results}

Table 1 shows the demographic characteristics of both patients and control groups. Mean age of patients was $5.253 \pm$ 4.80 years for SRNS (range from 2 to 17 ) and $7.7037 \pm 2.829$ for SSNS (age range from 2 to 15 years), while mean age at diagnosis was $5.420 \pm 4.114$ years for SRNS and $4.666 \pm 2.650$ years for SSNS. Three age groups for age of presentation and age of diagnosis are shown in Table 1.

Older age group (12-18 years) were all SRNS at time of presentation and time of diagnosis with no SSNS children $(P$ value $=0.005$ and 0.038 , resp.).

Correlation between gender and family history of NS of the two groups was statistically nonsignificant. The patients and control groups were compared according to their clinical data and laboratory investigations as shown in Table 2. The difference was statistically significant regarding hypertension, hematuria, renal insufficiency, mean of blood urea, and mean s. creatinine level, while no significant correlation was found with serum albumin.

Renal biopsy was performed for 21 patients; results are shown in Table 3.

\section{Genetic Results}

In Table 4, genetic results were put in form of G allele (VIC labeled) representing the wild type and A allele (FAM labeled) representing the polymorphism, and comparison between patients and control has been done.

The wild type allele was found in 16 (59.3\%) and the polymorphic allele (FAM) was found in 26 (96.3\%) of SRNS 
TABLE 2: Patient distribution according to clinical data and laboratory investigations.

\begin{tabular}{|c|c|c|c|c|c|}
\hline \multirow{2}{*}{ Data } & \multicolumn{2}{|c|}{ SRNS } & \multicolumn{2}{|c|}{ SSNS } & \multirow{2}{*}{$P$ value } \\
\hline & Number & $\%$ & Number & $\%$ & \\
\hline \multicolumn{6}{|l|}{ Hypertension } \\
\hline Hypertensive & 16 & 59.3 & 2 & 7.4 & \multirow{2}{*}{0.000} \\
\hline Normotensive & 11 & 40.7 & 25 & 92.6 & \\
\hline \multicolumn{6}{|l|}{ Hematuria } \\
\hline Hematuria & 9 & 33.3 & 1 & 3.7 & \multirow{2}{*}{0.005} \\
\hline No hematuria & 18 & 66.7 & 26 & 96.3 & \\
\hline \multicolumn{6}{|l|}{ Renal insufficiency } \\
\hline RI & 8 & 29.6 & 0.00 & 0.00 & \multirow{2}{*}{0.002} \\
\hline No RI & 19 & 70.4 & 27 & 100 & \\
\hline \multicolumn{6}{|c|}{ Mean s. albumin, g/L (mean \pm SD) } \\
\hline $2.400 \pm 0.889$ & & & \multicolumn{2}{|c|}{$2.525 \pm 0.867$} & 0.601 \\
\hline \multicolumn{6}{|c|}{ Mean blood urea, $\mathrm{mmol} / \mathrm{L}($ mean $\pm \mathrm{SD})$} \\
\hline $6.499 \pm 3.491$ & & & \multicolumn{2}{|c|}{$4.149 \pm 1.405$} & 0.002 \\
\hline \multicolumn{6}{|c|}{ Mean s. creatinine, $\mathrm{mmol} / \mathrm{L}($ mean $\pm \mathrm{SD})$} \\
\hline $79.518 \pm 73.150$ & & & \multicolumn{2}{|c|}{$47.696 \pm 14.904$} & 0.031 \\
\hline
\end{tabular}

TABLE 3: Renal biopsy results of 21 patients.

\begin{tabular}{lcc}
\hline & & Steroid responsiveness \\
& Steroid-sensitive & Steroid-resistant \\
\hline Minimal change disease & $3(75.0 \%)$ & $8(47.0 \%)$ \\
Focal segmental glomerulosclerosis & $1(25.0 \%)$ & $7(41.1 \%)$ \\
Mesangioproliferative & $0(0.0 \%)$ & $2(11.7 \%)$ \\
Total & 4 & 17 \\
\hline
\end{tabular}

patients. In the control group, the wild allele was found in 11 $(40.7 \%)$ and the polymorphic allele was found in 27 (100\%). The difference between these readings was nonsignificant $P$ value.

The genotype was divided into homozygous wild gene $(\mathrm{G} / \mathrm{G})$, homozygous polymorphic gene (A/A), and heterozygous gene (G/A). No significant statistical difference was found between the two groups regarding the 3 genotypes.

In Table 5, clinical data and disease progression of 53 children with heterozygous and homozygous polymorphic R229Q were compared. No significant correlation was found regarding mean ages at diagnosis, gender, consanguinity, family history of NS, hypertension, steroid responsiveness, renal insufficiency, and renal biopsy results.

\section{Discussion}

In the present study, males predominated in both patients (SRNS) group and control (SSNS) group with slight difference. This is similar to many other studies from different regions [11-16]. Consanguinity was found in high percentage in both groups, which is expected in this community because of social traditions. This is important to be surveyed in all nephrotic children to relate this disease to its associated genes and the type of inheritance.

Coming to the genetic results found in this study, the polymorphism R229Q was found in 26 (96.3\%) of 27 children with SRNS in both heterozygous and homozygous genotypes. A lower percent of this polymorphism was found by many studies $[11,13,15,16]$. In addition, several other studies did not report any polymorphism in SRNS [7, 8, 12, 16, 17]. The polymorphism R229Q was found 100\% among SSNS group in both homozygous and heterozygous genotype, which is much less than its frequency in Landau et al. [14], who did not find any, as well as Lahdenkari et al. [18] and Caridi et al. [19].

The present results are important, because the frequency of R229Q polymorphism of NPHS2 mutation among Iraqi children is largely unknown. This is because a small number of founding individuals and a high rate of consanguineous and endogamous marriages, typical of small communities, increase genetic homogeneity and highlight susceptibility genes.

In this study, obvious genotype/phenotype correlation regarding age at diagnosis, sex, consanguinity, family history, hypertension, renal insufficiency, and renal histology in both homozygous and heterozygous patients were not observed.

Such findings were similarly mentioned by several studies $[13,17,20,21]$. While Phelan et al. found that R229Q polymorphism was associated with early onset childhood SRNS [22], Sadowski et al. found FSGS in 68\% of R229Q polymorphism [23] and Tsukaguchi et al. found R229Q polymorphism associated with late-onset SRNS [24].

This polymorphism is prevalent among Czech (12\%), Spanish (3.1\%), French (4.5\%), Brazilian (3.1\%), and Italian 
TABLE 4: The frequency of genotyping in patients and control groups.

\begin{tabular}{|c|c|c|c|c|c|}
\hline \multirow{2}{*}{ Alleles } & \multicolumn{2}{|c|}{ SRNS } & \multicolumn{2}{|c|}{ SSNS } & \multirow{2}{*}{$P$ value } \\
\hline & Number & $\%$ & Number & $\%$ & \\
\hline G (VIC) & 16 & 59.3 & 11 & 40.7 & 0.174 \\
\hline $\mathrm{A}(\mathrm{FAM})$ & 26 & 96.3 & 27 & 100 & 0.313 \\
\hline \multicolumn{6}{|l|}{ Genotype } \\
\hline G/G & 1 & 3.7 & 0 & 0.0 & 0.313 \\
\hline $\mathrm{G} / \mathrm{A}$ & 15 & 55.6 & 11 & 40.7 & 0.267 \\
\hline A/A & 11 & 40.7 & 16 & 59.3 & 0.174 \\
\hline
\end{tabular}

TABLE 5: The clinical data and disease progression of 53 children with heterozygous and homozygous polymorphic R229Q.

\begin{tabular}{|c|c|c|c|}
\hline Parameter & Heterozygous GA $(n=26)$ & Homozygous AA $(n=27)$ & $P$ value \\
\hline Age at diagnosis (year \pm SD) & $4.853 \pm 3.777$ & $5.079 \pm 3.144$ & $0.814^{*}$ \\
\hline Male/female & $16 / 10$ & $20 / 7$ & $0.328^{*}$ \\
\hline Consanguinity & 21 & 18 & $0.244^{*}$ \\
\hline Family history & 5 & 2 & $0.204^{*}$ \\
\hline Hypertension & 9 & 8 & $0.697^{*}$ \\
\hline Renal insufficiency & 5 & 3 & $0.409^{*}$ \\
\hline \multicolumn{4}{|l|}{ Response to steroids } \\
\hline SRNS & 15 & 11 & \multirow{2}{*}{$0.217^{*}$} \\
\hline SSNS & 11 & 16 & \\
\hline \multicolumn{4}{|l|}{ Renal biopsy } \\
\hline MC & 6 & 5 & \multirow{3}{*}{$0.920^{*}$} \\
\hline FSGS & 5 & 3 & \\
\hline MP & 1 & 1 & \\
\hline
\end{tabular}

(3.2) $[16,25]$. The highest frequency of R229Q, after Czech population, has been reported in Chileans and Argentineans (7.3\%) [26]. The R229Q polymorphism has a lower frequency among Africans, African-Americans, and Asians (zero to $1.5 \%)[16,27]$. Tryggvason and colleagues proposed that R229Q, which is present in around 4\% of European populations, is associated with an increased risk of microalbuminuria [28]. Pereira and colleagues found that p.R229Q was associated with a 2.77 -fold increased risk of microalbuminuria [29].

Both SRNS and SSNS in the present study did not show a significant difference regarding the polymorphism. It seems that at least one polymorphic allele of R229Q may participate in their nephrotic process, and by this a conclusive role in steroid resistance was not reached. In order to reach a conclusive decision about the role of R229Q in the pathogenicity of nephrotic syndrome, its association with other exon mutations of the NPHS2 gene must be searched for in the same study groups. Its exact frequency in the Iraqi population needs to be determined as well, by studying the frequency of this polymorphism in normal nonnephrotic children and comparing the findings with those of affected ones. Studying other exon mutations including the most reported pathologic ones like mutations in exons 7 and 8 of the same gene is necessary to unravel the pathogenesis of
SRNS in Iraqi children. Of no less importance is studying other nephrotic syndrome genes. These topics are put into consideration as future perspectives of the present work.

\section{Conflicts of Interest}

The authors declare that there are no conflicts of interest regarding the publication of this paper.

\section{References}

[1] P. Niaudet and O. Boyer, "Idiopathic nephrotic syndrome in children: clinical aspects," in Pediatric Nephrology, E. D. Avner, W. E. Harmon, P. Niaudet, N. Yoshikawa, F. Emma, and L. S. Goldstein, Eds., pp. 839-869, Lippincott Williams \& amp; Wilkins, Philadelphia, Pa, USA, 7th edition, 2016.

[2] J. Floege and J. Feehally, "Introduction to glome-rular disease: clinical presentations," in Comprehensive Clinical Nephrology, R. J. Johnson, J. Feehally, and Floege J., Eds., pp. 184-197, Mosby, Philadelphia, Pa, USA, 5th edition, 2015.

[3] T. J. Stephen and N. Alexander et al., "NPHS2 variation in focal and segmental glomerulosclerosis," BMC Nephrology, vol. 9 Article 13, 2008.

[4] J. Sharma and A. Vasudevan, "Normal reference values of blood and urine chemistries," in Manual of Pediatric Nephrology, K. 
Phadke, P. Goodyer, and M. Bitzan, Eds., pp. 533-610, Springer, London, UK, 2014.

[5] C. S. Wong and R. H. Mak, "Chronic kidney disease," in Clinical Pediatric Nephrology, K. K. H. Kher, S. H. W. William, and S. P. Makker, Eds., pp. 339-352, Informa Ltd, London, UK, 2nd edition, 2007.

[6] G. Chernin, S. F. Heeringa, R. Gbadegesin et al., "Low prevalence of NPHS2 mutations in African American children with steroid-resistant nephrotic syndrome," Pediatric Nephrology, vol. 23, no. 9, pp. 1455-1460, 2008.

[7] D. Rachmadi, A. Melani, and L. Monnens et al., "NPHS2 gene mutation and polymorphisms in indonesian children with steroid-resistant nephrotic syndrome," Open Journal of Pediatrics, vol. 5, no. 1, pp. 27-33, 2015.

[8] Z. B. Özçakar, F. B. Cengiz, N. Çakar et al., "Analysis of NPHS2 mutations in Turkish steroid-resistant nephrotic syndrome patients," Pediatric Nephrology, vol. 21, no. 8, pp. 1093-1096, 2006.

[9] N. Franceschini, K. E. North, J. B. Kopp, L. Mckenzie, and C. Winkler, "NPHS2 gene, nephrotic syndrome and focal segmental glomerulosclerosis: a HuGE review," Genetics in Medicine, vol. 8, no. 2, pp. 63-75, 2006.

[10] R. G. Ruf, A. Lichtenberger, S. M. Karle et al., "Patients with mutations in NPHS2 (podocin) do not respond to standard steroid treatment of nephrotic syndrome," Journal of the American Society of Nephrology, vol. 15, no. 3, pp. 722-732, 2004.

[11] R. Gbadegesin, B. Bartkowiak, and P. J. Lavin et al., "Exclusion of homozygous PLCE1 (NPHS3) mutations in 69 families with idiopathic and hereditary FSGS," Pediatric Nephrology, vol. 24, no. 2, pp. 281-285, 2009.

[12] D. N. Feng, Y. H. Yang, D. J. Wang et al., "Mutational analysis of podocyte genes in children with sporadic steroid-resistant nephrotic syndrome," Genetics and Molecular Research, vol. 13, no. 4, pp. 9514-9522, 2014.

[13] A. Berdeli, S. Mir, O. Yavascan et al., "NPHS2 (podicin) mutations in Turkish children with idiopathic nephrotic syndrome," Pediatric Nephrology, vol. 22, no. 12, pp. 2031-2040, 2007.

[14] D. Landau, T. Oved, D. Geiger, L. Abizov, H. Shalev, and R. Parvari, "Familial steroid-sensitive nephrotic syndrome in Southern Israel: clinical and genetic observations," Pediatric Nephrology, vol. 22, no. 5, pp. 661-669, 2007.

[15] G. Chernin, S. F. Heeringa, and V. Vega-Warner et al., "Adequate use of allele frequencies in Hispanics-a problem elucidated in nephrotic syndrome," Pediatric Nephrology, vol. 25, no. 2, pp. 261-266, 2010.

[16] J. Reiterova, H. Safrankova, and L. Obeidova et al., "Mutational analysis of the NPHS2 gene in Czech patients with idiopathic nephrotic syndrome," Folia Biol (Praha), vol. 58, pp. 64-68, 2012.

[17] K. Ismaili, K. M. Wissing, F. Janssen, and M. Hall, "Genetic forms of nephrotic syndrome: a single-center experience in Brussels," Pediatric Nephrology, vol. 24, no. 2, pp. 287-294, 2009.

[18] A.-T. Lahdenkari, M. Suvanto, E. Kajantie, O. Koskimies, M. Kestilä, and H. Jalanko, "Clinical features and outcome of childhood minimal change nephrotic syndrome: is genetics involved?" Pediatric Nephrology, vol. 20, no. 8, pp. 1073-1080, 2005.

[19] G. Caridi, M. Gigante, P. Ravani et al., "Clinical features and long-term outcome of nephrotic syndrome associated with heterozygous NPHS1 and NPHS2 mutations," Clinical Journal of the American Society of Nephrology, vol. 4, no. 6, pp. 10651072, 2009.
[20] M. Schultheiss, R. G. Ruf, B. E. Mucha et al., "No evidence for genotype/phenotype correlation in NPHS1 and NPHS2 mutations," Pediatric Nephrology, vol. 19, no. 12, pp. 1340-1348, 2004.

[21] K. Tory, D. K. Menyhárd, S. Woerner et al., "Mutation-dependent recessive inheritance of NPHS2-associated steroid-resistant nephrotic syndrome," Nature Genetics, vol. 46, no. 3, pp. 299304, 2014.

[22] P. J. Phelan, G. Hall, D. Wigfall et al., "Variability in phenotype induced by the podocin variant R229Q plus a single pathogenic mutation," Clinical Kidney Journal, vol. 8, no. 5, pp. 538-542, 2015.

[23] C. E. Sadowski, S. Lovric, and S. Ashraf et al., "A single-gene cause in $29.5 \%$ of cases of steroid-resistant nephrotic syndrome," J Am Soc Nephrol, vol. 26, pp. 1279-1289, 2015.

[24] H. Tsukaguchi, A. Sudhakar, T. C. Le et al., "NPHS2 mutations in late-onset focal segmental glomerulosclerosis: R229Q is a common disease-associated allele," Journal of Clinical Investigation, vol. 110, no. 11, pp. 1659-1666, 2002.

[25] Z. Yu, J. Ding, J. Huang et al., "Mutations in NPHS2 in sporadic steroid-resistant nephrotic syndrome in Chinese children," Nephrology Dialysis Transplantation, vol. 20, no. 5, pp. 902-908, 2005.

[26] E. Machuca, A. Hummel, F. Nevo et al., "Clinical and epidemiological assessment of steroid-resistant nephrotic syndrome associated with the NPHS2 R229Q variant," Kidney International, vol. 75, no. 7, pp. 727-735, 2009.

[27] S. Santín, B. Tazón-Vega, I. Silva et al., "Clinical value of NPHS2 analysis in early- and adult-onset steroid-resistant nephrotic syndrome," Clinical Journal of the American Society of Nephrology, vol. 6, no. 2, pp. 344-354, 2011.

[28] K. Tryggvason, J. Patrakka, and J. Wartiovaara, "Hereditary proteinuria syndromes and mechanisms of proteinuria," The New England Journal of Medicine, vol. 354, no. 13, pp. 1387-1401, 2006.

[29] A. C. Pereira, A. B. Pereira, G. F. Mota et al., "NPHS2 R229Q functional variant is associated with microalbuminuria in the general population," Kidney International, vol. 65 , no. 3, pp. 1026-1030, 2004. 


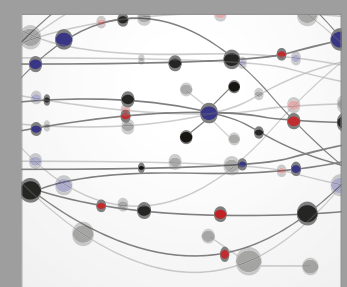

The Scientific World Journal
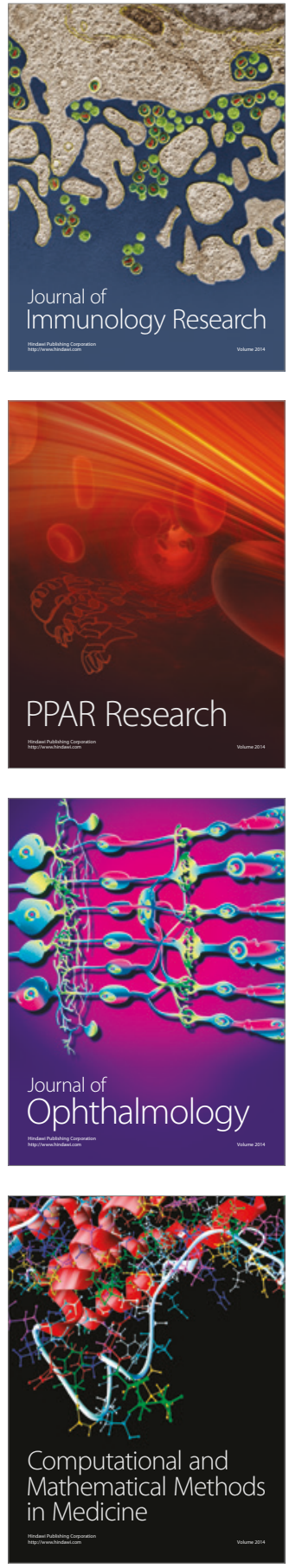

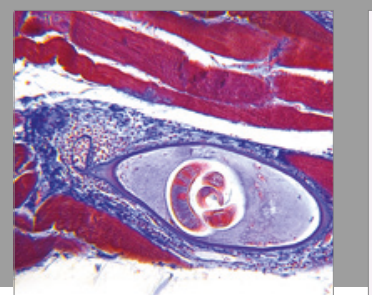

Gastroenterology Research and Practice
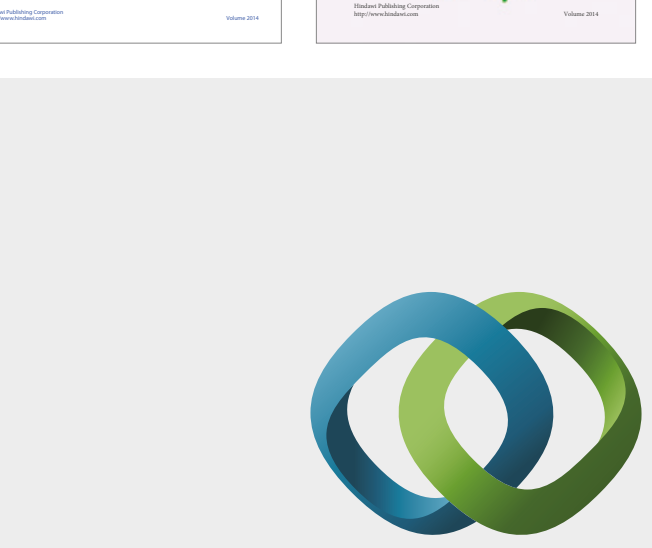

\section{Hindawi}

Submit your manuscripts at

https://www.hindawi.com
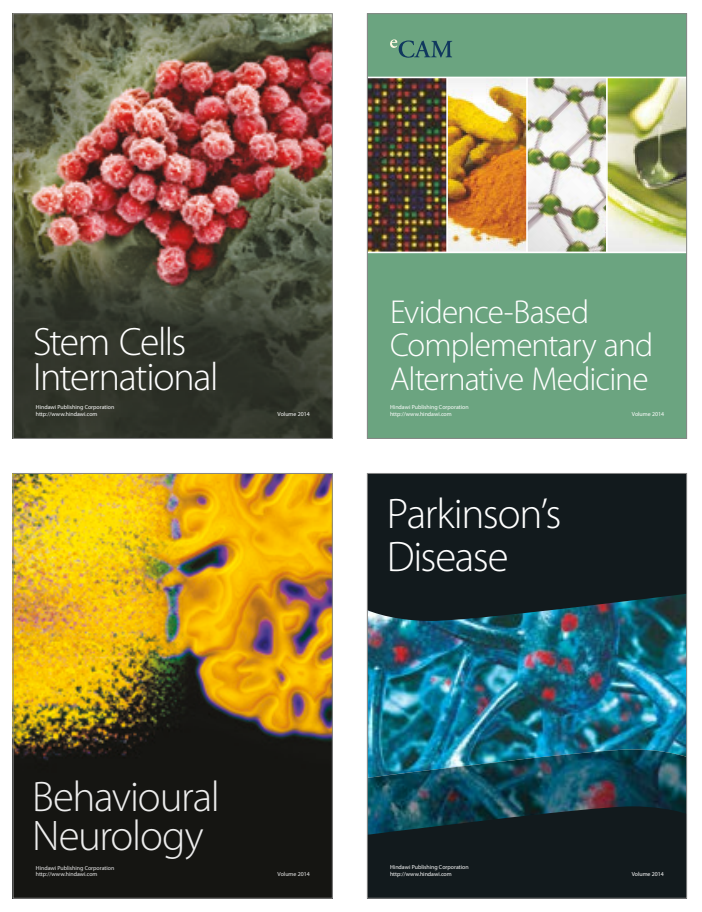
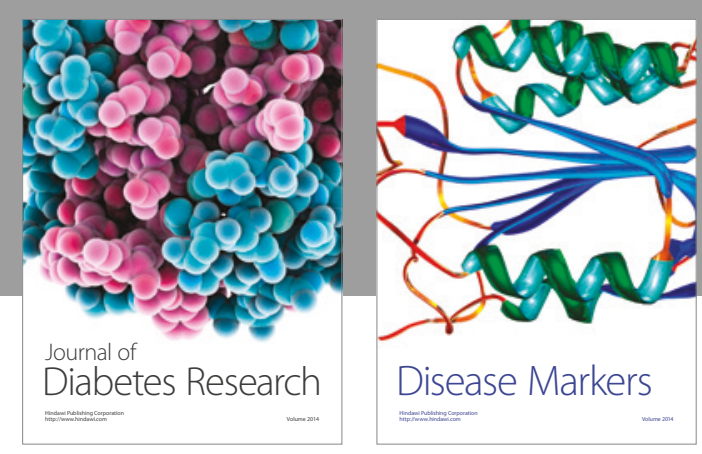

Disease Markers
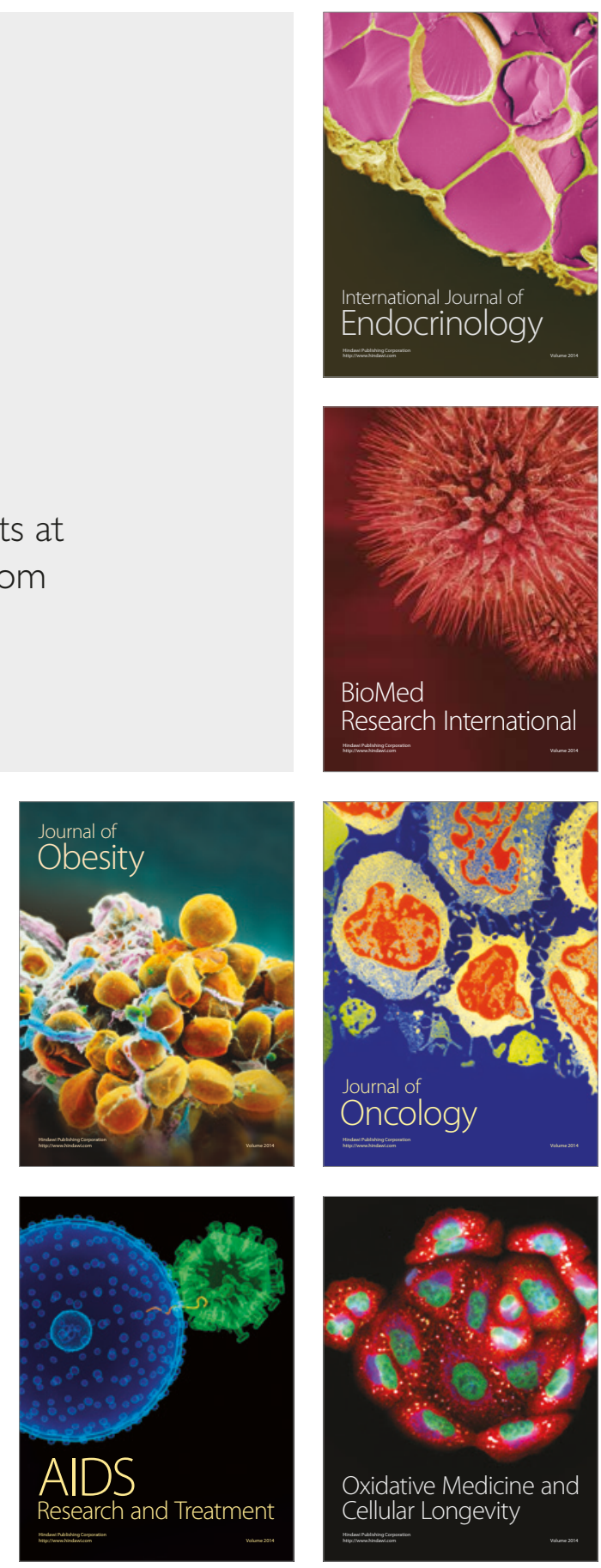